\title{
Cultural differences of female enrolment in tertiary education in computer science
}

\author{
Britta Schinzel \\ Institut für Informatik und Gesellschaft, Universität Freiburg,Germany
}

\begin{abstract}
Since the establishment of computer science courses, over the last 30 to 40 years both female enrolment and its progression differ strongly between various continents, countries, cultures, religions and languages. It is remarkable that female participation is extremely low in German (and Dutch) speaking countries, in Scandinavian countries and Great Britain, compared to the other European countries. In many Western countries female participation in computer science courses has dropped since 1970 by more than 50 percent. This has not occurred in semi-developed countries, like those in South America, the rich Arab countries, the Tiger states or India, nor has it occurred in the developmental countries in Africa. In this paper I give explanations and theories for these differences. It will be shown that there is no evidence for natural explanations of competence and interest in computing, mathematical and technical subjects. The findings in turn may give hints abut how to change the situation of women entering computing within our culture.
\end{abstract}

Key words: female enrolment in computer science courses

\section{SOME EXAMPLES OF FEMALE ENROLMENT IN COMPUTER SCIENCE}

A quick glance at the proportion of female participation in science and engineering throughout the world (Table 1) reveals the extent to which gender distribution is culturally diversified. It is interesting to note that many of the so-called industrially developed countries are comparatively underdeveloped as far as the inclusion of women into these subjects is concerned. Another interesting observation is that within Europe the former socialist countries have had, and the Latin countries are having, a much higher female participation in science and engineering than in the Anglo-

The original version of this chapter was revised: The copyright line was incorrect. This has been corrected. The Erratum to this chapter is available at DOI: 10.1007/978-0-387-35615-0_52 
Saxon, Scandinavian and German-speaking countries. Within Europe Turkey, Spain and Portugal are recruiting most with respect to the inclusion of women in science and engineering in all stages of the career ladder. Also it is striking to note that quite a lot of African, and all the Arabic and South American countries have a nearly equal gender distribution in computer science (CS).

\begin{tabular}{|l|c|c|}
\cline { 2 - 3 } \multicolumn{1}{c|}{} & \multicolumn{2}{c|}{ Mathematics/computer science } \\
\hline Country & Total & \% Females \\
\hline Angola & na & na \\
\hline Burkina Faso & 433 & 5 \\
\hline Burundi & 77 & 34 \\
\hline Ethiopia & 468 & 9 \\
\hline Ghana & 206 & 11 \\
\hline Ghana & 206 & 11 \\
\hline Kenya & na & na \\
\hline Lesotho & na & na \\
\hline Niger & na & na \\
\hline Swaziland & na & na \\
\hline Uganda & 155 & 10 \\
\hline Zambia & na & na \\
\hline Zimbabwe & na & na \\
\hline Kuwait & 1635 & 72 \\
\hline Brazil & 70898 & 38 \\
\hline Mexico & 51751 & 41 \\
\hline Sweden & 6504 & 19 \\
\hline
\end{tabular}

Table 1. Enrolment for selected countries, showing total number of students and the percentage representation of females (Figures given represent enrolment in courses leading to a first degree) (Source: compiled from the UNESCO Statistical Yearbook, 1993) (na = not available because subsumed under another faculty)

Some actual numbers from some single universities show striking differences as well (information from Joel C. Adams, from lectures in Mauritius, 2001):

- University of Mauritius: 40-50\% women in CS courses.

- National University of Samoa: $60 \%$ of CS students are women.

\section{THE GERMAN SITUATION IN INFORMATICS}

There has been a constant rise in student enrolment in Germany since the nineteen seventies, but female participation has not risen to the same extent 
as male participation. During the 1980s and 1990s the fraction of females even decreased substantially. In contrast, female participation in the former GDR was equally distributed among the sexes.

\begin{tabular}{|c|c|c|c|}
\cline { 2 - 4 } \multicolumn{1}{c|}{} & All & Female & $\begin{array}{c}\text { \% of female CS- } \\
\text { students }\end{array}$ \\
\hline $1986 / 87$ & 60 & 39 & $65.00 \%$ \\
\hline $1987 / 88$ & 60 & 39 & $65.00 \%$ \\
\hline $1988 / 89$ & 133 & 49 & $36.84 \%$ \\
\hline $1989 / 90$ & 205 & 65 & $31.70 \%$ \\
\hline $1990 / 91$ & 241 & 49 & $20.33 \%$ \\
\hline $1991 / 92$ & 241 & 43 & $17.84 \%$ \\
\hline $1992 / 93$ & 261 & 44 & $16.86 \%$ \\
\hline $1993 / 94$ & 255 & 39 & $15.29 \%$ \\
\hline $1994 / 95$ & 236 & 36 & $15.25 \%$ \\
\hline $1995 / 96$ & 262 & 31 & $11.83 \%$ \\
\hline $1996 / 97$ & 294 & 25 & $8.50 \%$ \\
\hline $1997 / 98$ & 324 & 28 & $8.64 \%$ \\
\hline $1998 / 99$ & 359 & 30 & $8.36 \%$ \\
\hline
\end{tabular}

Table 2. Effects of the reunion of Germany on the female enrolment in computer science at the Technical University of Rostock (Source: University of Rostock)

After the reunion of Germany, the participation of women in the new German countries from former East Germany dropped to that of the West German level. Table 2 shows the incredible degree of decline of females participating in informatics within the new countries. Similar effects have occurred in Hungary (according to a colleague in Budapest this is about a $10 \%$ fall at the University of Budapest in 2000), but not in all of the former socialist countries.

\section{THE SHRINKING PIPELINE}

A different, but also context-dependent effect is the shrinking of female enrolment in computer science in some countries, like the USA (Camp, 1997), in German (and Dutch) speaking countries, in Scandinavian countries and Great Britain and in Israel, often in contrast to all other subjects. In general in Western countries the interest in science and technology is sinking 
in second and third level education. Rising numbers are only seen in China, India and in the four Tiger countries. Within this general trend female percentages in western societies are rising in proportion within these subjects. But even in this situation female participation has fallen in computer science since 1985, for example, in Germany up to a half or more.

There has been no such effect in the Latin countries at the same time. In other countries, like Turkey, where the number of women taking computer education was constantly high, a decline has started later, at the end of the nineties, probably due to the introduction of the internet (personal information from a Turkish colleague).

The German female enrolment in CS shows the shrinking effect over the last 15 years, but it also shows a slight improvement during the last two years (the latter, although highly appreciated, is not yet understood. It could be a result of: the enforcement of the labour market due to the lack of computer professionals in Germany; and/or of the summer university Informatica Feminale in Bremen, which gives women a lot of encouragement; the more diversified informatics courses, with possibilities for interdisciplinarity; and/or of the rising availability of computers in families, also for girls; and/or the new and more social qualities of software, availability of better computer games, etc.

\section{ADDITIONAL DIVERSIFICATION OF FEMALE ENROLMENT ACCORDING TO UNIVERSITY TYPES}

Camp (1997) found that graduates in CS in engineering colleges, on average, have proportionately fewer women than in non-engineering colleges. On the other hand, at the level of $\mathrm{PhD}$ degrees, the percentages, though still meagre, increased. This has been observed for more than 10 years in the US. We find that the same effect has occurred recently in Germany as well, with technical universities as opposed to classical (such as the Humboldt) universities and especially to interdisciplinary courses of study in informatics - and that the percentage of female assistants willing to achieve a $\mathrm{PhD}$ in informatics is often larger than the percentage of informatics students.

More specialised courses recently are showing significant effects as a result of gender differences as well: the more technically defined (i.e. named), the smaller the female participation, while the more interdisciplinary and application defined, the greater the female participation (for example, Furtwangen 2000/01 shows: Technical 0.0\% females, Media Informatics $27.8 \%$ females). 
We have recently investigated the participation of women in the IT work force as well as in all types of tertiary education within the province of Baden-Württemberg. Particularly in the educational sector there is a strong dependency on contexts. The more emphasis on 'dressing' and description put on technology and engineering, the less women are interested, while the more the subject is considered as interdisciplinary, the more it is put into a social context, the more women are participating, even if the subject itself is mostly technical (such as media informatics).

\section{INTERPRETATIONS OF GENDER DIFFERENCES IN COMPUTER SCIENCE BETWEEN DIFFERENT CULTURES}

The factors attributed to the diversification of gender differences existing between the 'industrially developed', the 'semi-developed' countries, like those in South East Asia and South America, and the 'developing' countries, like the south Sahara African countries also include the effects of the class system, the different roles of universities, and the rate of income in science and engineering.

The class system has been a predominant factor in the 'semi-developed' countries (like India, Brazil or Argentina), where only upper class people could afford to send their children to university and they equally let their boys and girls study. Especially in these countries, there seems to be no conviction like that in North-West Europe, stereotyping women as less capable of pursuing education in science and technology. Another important factor is that household and childcare work (which are often supposed to be the spheres of females) are delegated to employees, a fact which enables these women to join the labour market with commitment just like men. Moreover, it is presumed (wrongly, as is obvious for example, for India or Korea) that the university standards are considered to be not as competitive and high as in the "industrially developed" countries, making the courses of study less hard and stressful. Besides, the emphasis of these universities is supposed to lie more at an educational than on a scientific level, a circumstance which offers studying and university careers closer to standard female gender roles. As a consequence the teaching personnel in these countries are less gender diversified, giving role models for women as well. But again India and the four Tiger states cannot be put into this scheme and it is quite ironic to note that especially 
in these countries there seem to be strong differences with regard to cultural and symbolic constructions of gender.

The extremely high participation of women in engineering and computer science within the North African and the Arab countries can on the one hand be explained by different subject-specific gendering: religion is a male enterprise, but technology is not gendered. But on the other hand also the gender splitting might be of importance: there is no co-education at any level of education in these countries. That co-education, especially during puberty, affects female participation in science and engineering is widely explored, especially in the north-western countries of Europe and America. But it is important to note that it does not impact everywhere (for example, Italy)!

But why did the percentage of women in the former socialist countries collapse immediately after reunion? This is easily explained: there was an explicit policy to draw women from the job market. Kindergartens were closed, (from the 'old countries of Germany' imported) politicians declared that female work had to be reduced to a 'normal' (i.e. West German) size. From 1990 to 1992 most jobs in the former DDR were evaluated (abgewickelt), a procedure where most people lost their jobs. In engineering men regained their old or other jobs, but women did not (Burkhard, 1997). Of course this was not encouraging for women to take up a study in informatics or engineering. The effect is the one which was sought.

Particularly interesting and difficult to explain are the considerable differences within Europe, which show less gender segregation in the Latin and the Slavonic countries, as well as in Turkey.

There seems to exist a deeply founded desire to 'perform gender' in some way or the other. If gender differences are institutionally guaranteed or culturally fixed, as it might also be by visible marking, such as dress order or hairstyle/beard, or by a clear hierarchy within family work, then this performance of gender difference can be satisfied without a gender marking of competence. This seems to hold also for the Catholic Latin and Slavic cultures within Europe, where a stronger body performance of gender is shown than in the Protestant cultures. In the Catholic countries there exist more specified gender cultures, which allow individuals of both sexes to have self-conscious gender identities. This cultured behaviour is performed mainly in the social interactions between men and women away from their workplace and it confirms their respective self-esteem as women or men. In the Balkans and in Italy, Spain and Portugal, there exist very distinctive and self-confident gender cultures, both concerning the role of mothers of all generations and amongst the youth,when meeting and 'showing off' in open places. In Russia the common conviction that men are incapable of organising everyday life (and often also professional life) gives women a fairly self-conscious gender identity, still not putting differences into 
question. So there is no necessity for boys or men to hold their ground in mathematics, science or engineering to stabilise their male identity, and women can more easily consider themselves of equal intellectual ability, including fields like computer science. They need not take distance from engineering and IT to perform femaleness, as it is often observed in the north-western European countries.

Societies tend to uphold gender hierarchies by reproducing gendering, especially in highly respected fields like IT. Therefore it appears that there exists a need in the Protestant cultures to create the difference individually and by deliberate action and that this action has to be marked symbolically. As a consequence gender differences evolve context dependently, and their creation becomes a process with many prerequisites bound to specific constellations and to different areas of human activity. Therefore in certain contexts gender differences can be dissolved, whereas in others they can be maintained or even be strengthened, as is the case within the higher valued IT job market in some areas of the world. Though gender as a factor of ordering society seems to lose its importance in the north-western European countries in general, it shows considerable persistence with respect to hierarchical structures, and it even gains importance on the symbolic level for the ordering of content, of scientific subjects, and of specific professions. The contextualisation of gender difference might be caused by open space, leaving the definition of gender identity much more to chance and to the individual. Unfortunately this free space frequently is not used in the sense of creating an identity which includes equal value. The gendering of competence creates a symbolic gendering of subjects, and with this comes borderlines between, and social closures for, men and women.

\section{REFERENCES}

Augustine, D.L. (1999) The "Socialist Silicon Ceiling": East German Women in Computer science. In A. Brown and D. Morton (eds.). Proceedings of the 1999 International Symposium on Technology and Society: Women and Technology: Historical, Societal, and Professional Perspectives.

Barinaga, M. (1993) Science Education: The pipeline is leaking women all the way along. Science, Vol. 260, 16 April 1993

Breckler, S.J. and Wiggins, E.C. (1991) Cognitive Responses in Persuasion: Effective and Evaluative Determinents. Journal of Experimental Social Psychology, 27, 180-200

Burkhard, A. (1997) New Professors-Old Structures: Results of personnel replacement in East German universities from women's point of view. In A.F. Grundy et al. (eds.) Women, Work and Computerization; Spinning a web from past to future. Proceedings of the Sixth International IFIP Conference on Women, Berlin. Heidelberg, N.Y.: Springer

Camp, T. (1997) The incredible shrinking pipeline. Communications of the ACM, 40, 10, 103-110 
Hannover, B., Scholz, P. and Laabs, H.J. (1992). Technikerfahrung und mathematischnaturwissenschaftliche Interessen bei Mädchen und Jungen. ein Vergleich zwischen Jugendlichen aus den alten und den neuen Bundesländern. Zeitschrift für Entwicklungspsychologie und pädagogische Psychologie, 24, 2, 115-128

Zachmann, K. (1997) Frauen für die Technische Revolution. Studentinnen und Absolventinnen Technischer Hochschulen in der SBZ/DDR. In G. Budde (ed.) Frauen arbeiten. Weibliche Erwerbstätigkeit in Ost- und Westdeutschland nach 1945. Göttingen: Vandehoeck und Ruprecht

\section{BIOGRAPHY}

Britta Schinzel studied mathematics and physics, worked in the computer industry and then came back to university as a computer scientist. 